\title{
Workers' perception of hazards on recycling sorting facilities in São Paulo, Brazil
}

\author{
Percepção dos trabalhadores quanto aos perigos \\ em centrais de triagem de recicláveis em São Paulo, Brasil
}

Ana Maria Maniero Moreira ${ }^{1}$

Wanda Maria Risso Günther ${ }^{1}$

Carlos Eduardo Gomes Siqueira ${ }^{2}$

${ }^{1}$ Faculdade de Saúde Pública, Universidade de São Paulo. São Paulo SP Brasil. anamariainforme@ hotmail.com

${ }^{2}$ School for the

Environment, University

of Massachusetts. Boston

Massachusetts EUA.

\begin{abstract}
The paper discusses views, perceptions, experiences, knowledge and behaviors related to occupational risks among recycling workers. Data collection involved field observation and two focus groups in each site. Narratives were recorded, transcribed, and analyzed for themes. Findings are presented according to the following topics: economic and environmental value of recycling; aspects of employment in the cooperative system; occupational hazards; and suggestions of improvements. Municipal programs of selective collection, as implemented in most Brazilian municipalities, still need improvements to achieve their goals and objectives. We learned that organizing recycling workers in cooperatives, despite its broad acceptance as a replacement to informal garbage collection in streets and landfills, only brought small progress regarding the safety and quality of life of cooperative workers. Recycling workers noticed the existence of workplace hazards, but seemed resigned to the situation, considered them as part of the job and did not communicate their needs to supervisors. They ignored the existence of some measures to prevent hazards and sometimes even created work practices and alternatives that endangered their own health.

Key words Recycling, Recycling workers, Work environment, Occupational risk, Hazardous Waste
\end{abstract}

Resumo O artigo discute pontos de vista, percepções, experiências, conhecimentos e comportamentos relacionados aos riscos ocupacionais entre os trabalhadores de reciclagem. Coleta de dados envolveu observação de campo e dois grupos focais em cada unidade. Narrativas foram gravadas, transcritas e analisadas por temas. Resultados são apresentados de acordo com os seguintes tópicos: valor econômico e ambiental da reciclagem; aspectos do sistema cooperativista; riscos ocupacionais e sugestões de melhorias. Programas municipais de coleta seletiva, tal como implantados na maioria dos municípios brasileiros, ainda precisam de melhorias para atingir suas metas e objetivos. Aprendemos que a organização de trabalhadores da reciclagem em cooperativas, apesar de sua ampla aceitação como um substituto para a coleta de lixo informal nas ruas e aterros, trouxe pouco progresso em relação à segurança e qualidade de vida dos cooperados. Os trabalhadores notaram a existência de riscos no local de trabalho, mas parecem resignados com a situação, consideram como parte do trabalho e não comunicam as suas necessidades aos supervisores. Eles ignoraram a existência de algumas medidas para evitar riscos e, por vezes, até criam práticas de trabalho e alternativas que colocam em perigo a própria saúde.

Palavras-chave Reciclagem, Catadores, Ambiente de trabalho, Risco ocupacional, Resíduos perigosos 


\section{Introduction}

Global concern about solid waste has increased lately due to intensification of production and consumption, associated hazards and the lack of appropriate areas for final environmental dispos$\mathrm{al}^{1}$. It is recognized worldwide that recycling is an activity that contributes to waste minimization, and helps to improve both the local economy and the environmental health and sustainability.

Recycling is an important component of the waste management system. It allows for the return of recyclables to industry, the conservation of energy and natural resources, and the minimization of environmental impacts caused by waste treatment or final disposal in landfills ${ }^{2}$. In Brazil, recycling is one of the methods established by the current solid waste policy to minimize waste generation and to promote social inclusion. Selective collection programs have been encouraged and institutionalized as national public policy.

Thousands of people around the world earn a living by collecting and processing urban solid waste through informal systems, especially in low and middle-income countries ${ }^{3,4}$. Recycling workers are called catadores in Portuguese, whose occupation was legalized by the Brazilian Ministry of Labor and Employment in $2002^{5}$. These laborers constitute one of the most disadvantaged and vulnerable segments of the population ${ }^{4,6}$ since they work in poor conditions and earn very low and unstable incomes ${ }^{7}$. This situation is especially true for independent workers, such as those sorting at open dumps and streets, who constitute the informal recycling sector ${ }^{3,8}$.

Since the early 1990s, Brazilian municipalities have developed selective waste collection programs in partnership with recycling workers organized into cooperatives 9 . The purpose of these programs is to promote social inclusion, through work and income, and to provide better salaries and safe work conditions. At the same time, these programs will guarantee the legalization and formalization of the catador. Yet, Medeiros and Macêdo ${ }^{10}$ argue that this social inclusion has perverse characteristics. The catador is included by getting a job, but excluded by the type of work performed: precarious, in poor conditions, with a high degree of danger and insalubrity, without any social recognition, with health risks that are often irreversible, and without any labor rights. In addition, the catadores do not have access to education nor technical development.

Regardless of how they participate in the labor market, Brazilian workers usually are subject to the National Worker Health Policy. The Policy establishes guidelines and strategies for the development of comprehensive healthcare for workers and emphasizes occupational health surveillance. Furthermore, it prioritizes vulnerable workers, such as those whose jobs are informal and precarious, or those who have higher health risks, like garbage workers ${ }^{11}$.

Appropriate and favorable workplace conditions are important to improve occupational performance and productivity, promote worker safety and health, and implement the public policy model widely encouraged in the country. Hazardous and unhealthy working conditions have already been identified in sorting facilities all over the world. Recycling workers are exposed to biological, physical, chemical, ergonomic, and mechanical risks, all causing high rates of workplace injuries and illnesses ${ }^{2,12,13}$.

As reported by the Brazilian Ministry of Health $^{14}$, a good investigation of health-workdisease relation must consider workers' perceptions, both from an individual and a collective point of view. Perception is a result of a cognitive process whereby a person interprets information based on his or her understanding of an object. It is a belief or opinion that is frequently based on how things appear ${ }^{15}$. Often, only workers can describe the real conditions, circumstances, and unforeseen events that occur in their daily lives. Because of this, these workers can clarify the causes of their illnesses, which can lead to an improvement in risk policies ${ }^{16}$. On the other hand, Dejours ${ }^{17}$ argues that as condition worsen, workers perceive more risks. Conforming to this author, workers may ignore the limits of risk, its impacts, and prevention measures. However, workers will still recognize existing hazards and establish protective strategies in light of them.

Previous studies have already analyzed risk perception of catadores who worked in open dumps ${ }^{18,19}$ and waste triage facilities ${ }^{20}$. But this study applied integrated, participatory, and complementary approaches to answer the following question: How are recycling co-op workers perceiving and facing hazards in their daily work routine?

\section{Methodology}

This is an exploratory, qualitative study conducted in two Sorting Facilities (SF) of recyclable materials located in the city of São Paulo, Brazil, which we labeled as Co-op A and Co-op B. These units are samples of a total of 21 cooperatives of 
recycling workers that sort, process, trade, and sell recyclables collected by the Municipal Program of Selective Collection of this metropolis. Reasons to select those two units were the convenient location of the sites and their agreement to participate in this study.

Both units operate six days a week during regular business hours. While Co-op A has 43 members and Co-op B has 115, the number of workers in each vary constantly because both have high rates of absenteeism and turnover. Coop B has more than double membership, but approximately half rotate every trimester to work in a neighbor mechanized facility since July, 2014.

Data was collected through field observations and focus groups with members of the two cooperatives in August 2014. According to Gibbs ${ }^{21}$ and Kitzinger ${ }^{22}$, a focus group is the ideal method to explore people's experiences, attitudes, feelings, opinions, beliefs, reactions, wishes and concerns. One preliminary talk was held at each unit for most co-op members to present the aims of the study and invite them to participate in the groups. Eleven members in Co-op A and nine in Co-op B accepted to participate. This number of participants was considered sufficient and appropriate because it would allow everyone to share their diverse thoughts and opinions. Two meetings were scheduled in each cooperative with a two-week interval. To strengthen this study, a simplified version of PhotoVOICE was adopted. PhotoVOICE is a participatory action research method that employs photography and group dialogue as a means for marginalized individuals to deepen their understanding of a community issue or concern ${ }^{23}$. This method was previously used to investigate workplace hazards and promote solutions to eliminate or reduce them ${ }^{24}$. Photos of hazardous and uncomfortable situations at work were taken by volunteers (two from Co-op A and four from Co-op B) and later discussed in the second focus group. Some of those photos are shown below to illustrate workers' perception of workplace conditions.

At the start of the first focus group, participants were informed about the topics to be discussed and the rules. Everyone agreed to sign the informed consent document. Statements were audio and video taped (about 5 hours of recordings) and kept anonymous.

The first focus group at Co-op A included three men and eight women. One man and one woman did not attend the second group. Seven men and one woman participated in both focus groups in Co-op B. A total of ten males (53\%) and nine females (47\%) participated in both groups; the average age was 42.7 years old (ranging from 23 to 60 ) and seniority varied from 11

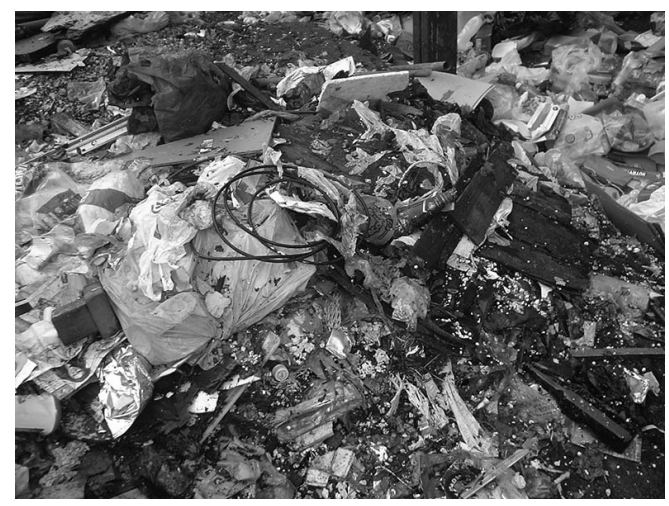

Figure 2. Material spread on the soil before sorting process in Co-op A.

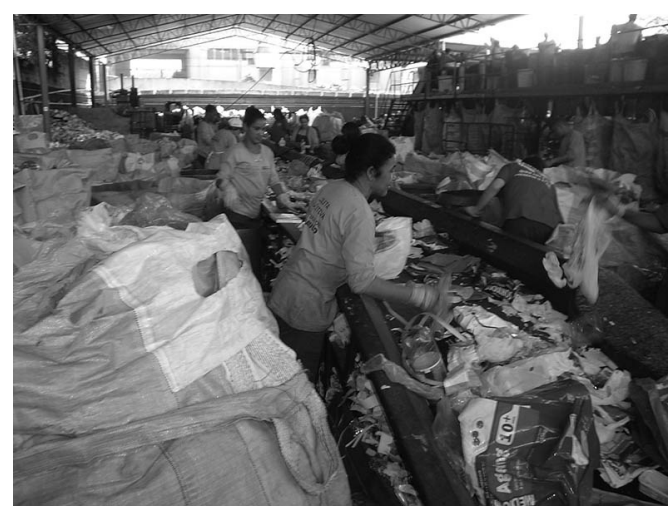

Figure 3. Workers sorting materials in the conveyor belt of Coop B.

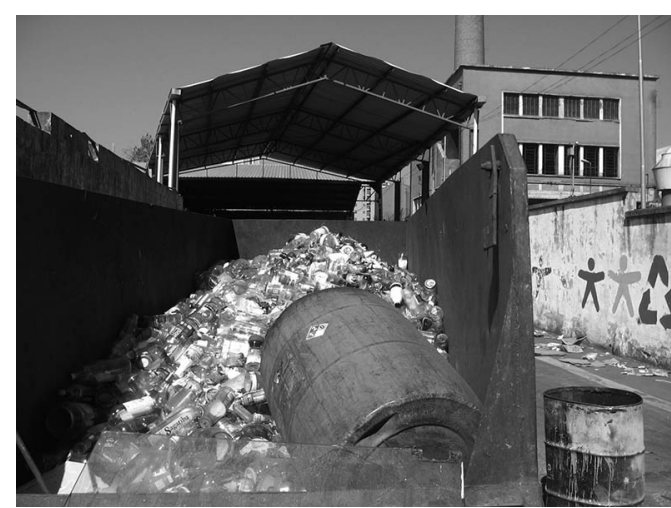

Figure 4. Container for storage of glass exposed to the weather at Co-op B. 
months to 10 years. The majority had low education levels. Only one finished college and three completed high school. Of the others, three were illiterate, three completed primary education and ten even had finished it. One member refused to answer. This diversity of gender, age, seniority, and level of education created a good balance between the two groups.

Finally, two presentations were conducted, one in each sorting facility, to give feedback to all co-op workers by sharing the partial results of the study and offering some basic safety guidelines on workplace accidents and disease prevention.

Data analysis was conducted following Bar$\operatorname{din}^{25}$ in four phases: a) organization of documents collected (field notes, photos and transcriptions of meetings); b) generation of hypotheses and objectives; c) summarization and categorization of data; and d) inference and interpretation of data, whereby themes were elicited and juxtaposed to each category of analysis, highlighting agreements and divergences.

An attempt was made to reproduce the colloquialism of the participants' statements when translating their Portuguese comments into English. Thus, when appropriate, pronunciation and grammar errors were marked with an asterisk.

This study was approved by the National Committee for Ethics in Research of Ministry of Health.

\section{Operational flow of sorting facilities}

The operational flow of the facilities (Figure 1) involve the following steps: a) manual unload of the arriving trucks on the floor, next to the conveyor belt; b) opening of plastic bags and removal of voluminous products such as cardboard and other big objects); c) segregation of recyclable materials by two lines of workers positioned on each side of the conveyor belt; d) throwing of recyclables collected into big bags or tubs, separated per type and subtype; e) continuous replacement of the full containers; f) pressing and bailing cardboards, plastics and cans; g) transportation of bales and tubs full of glass and iron pieces by forklifts; h) storage until commercial sale.

At the end of the conveyor belt, rejected materials fall on a big bag until it is full. Then, this big bag is dragged and emptied on a corner creating a great pile of trash.

\section{Results}

The focus groups raised relevant issues, such as the value of recyclable materials, advantages/ disadvantages of cooperativism, workplace risks and problems, in addition to suggestions for improvements. Participants freely reported their views, knowledge, practices, and experiences. Some statements were complemented with photographs that illustrate situations experienced in their workplaces. These testimonials are organized into five key categories to facilitate thematic content analysis, detailed below.

\section{Economic and environmental value of recycling}

Participants recognized the importance of their work and the value of the recyclable materials they sort out, both in environmental and economic terms. One worker stated that I learned that garbage has value: cup and bottle is ${ }^{*}$ not trash. Garbage is gold, it is not waste anymore, while two others added that ... To trash goes everything that has no value, but a lot of things are not supposed to be trash, and become recyclables to us and that Everything in here [recyclable materials] worth * gold to us. Several recycling workers expressed pleasure and even pride in working in the SF: People does ${ }^{*}$ not give value to the work that we have! But it's a very good job. Another worker expressed similar feelings and even described himself as an environmental steward: I love what I do here. We do not work with garbage. We clean up the planet and I'm proud to do what I do.

\section{Positive and negative aspects of working in cooperatives}

Only one worker showed dissatisfaction with employment conditions in cooperatives: I like to work here, but I would prefer to have working papers. I do not want to leave, but I want to get my benefits. Another co-op worker, though, preferred this kind of employment because it provides more independence. She showed resignation with the monthly pay and the drawbacks faced in her daily life: You want ${ }^{*}$ working papers? Here we have no boss, we work for ourselves. This is what a cooperative is! For me it is great because I can pay my bills, provide food for my kids. Despite some setbacks... but all places have, right? I left twice, but came back.

Due to the lack of formal employment, it is common for workers to quit and return later. 


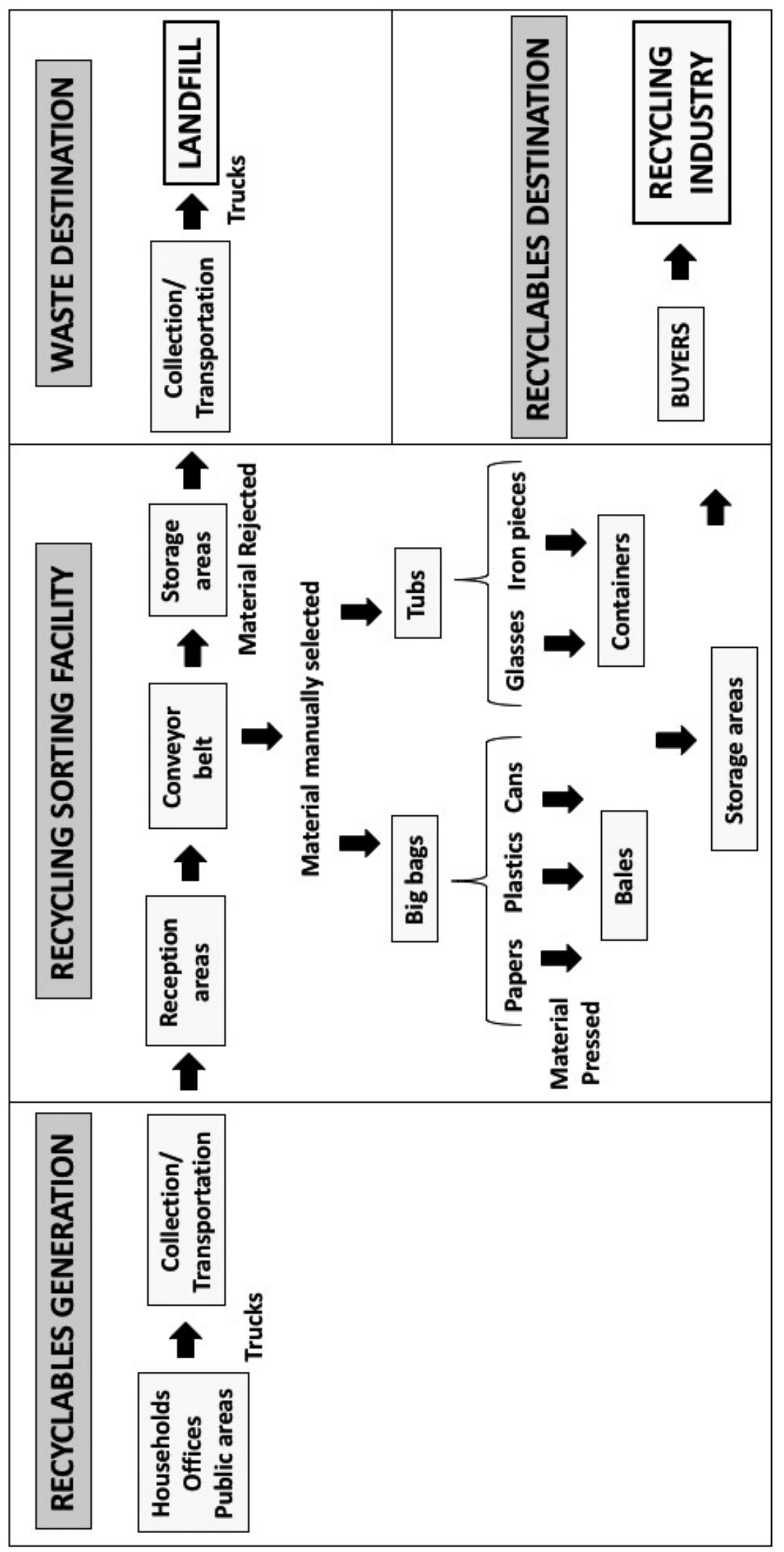

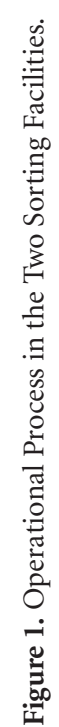


One participant noted: I also left the cooperative once, but I came back. I really like what I do. Despite the low education level, workers debated the relationship between productivity and income, as one emphasized: The more we produce, the more we earn. Then, the blame if $u^{*}$ earn little is on us, it's not on anyone's.

\section{Biological hazards}

One of the photos taken by a cooperative member generated discussion about infrastructure and operational problems (Figure 2). It portrays an open area in the back of Co-op A where large amounts of recyclable and non-recyclable materials in an advanced state of decay waited to be sorted. According to one participant Every day comes a lot of material and we do not catch up. And it spoils because it rains. So, it turns into trash. No longer serves for nothing*.

The absence of proper sites for storage exposed materials to weathering, affected their quality, reduced their added value for marketing, led to feelings of disgust by those who handle them, and attracted vectors of public health importance.

Participants commented on the unsanitary conditions of the materials: [when] it rains, water and mice come because it always has leftover food. ...And there is the stench. ... There are lots of cockroaches, insects, mice. This must carry diseases ... then it is even dangerous.

People frequently send decomposed food, disposable diapers, and used toilet paper by mistake to the SF. At the same time, products apparently in condition of consumption (fresh or processed food, sweets, dairy products, cosmetics, medicines, etc.) were also found in the conveyor belt (Figure 3) and consumed by the workers. This practice is common and worrisome because of potential adverse health effects to workers and their families.

In both cooperatives, all material rejected during the sorting process were deposited on the soil in predetermined areas, creating trash piles. Some workers seemed to know the associated risks: My criticism is about the waste they always leave accumulated. ...Usually, they [Municipal Cleaning Service] remove it two or three times a week. Sometimes it takes one week. ... This trash also stays exposed to the weather, accumulating water, rain, attracting mosquitoes and dengue. Only one co-op member showed great concern with the great number of pigeons that infest the site: Pigeons nest up there (on the pilasters) and poop, which dries and turns to dust, right? And this leads to health problem*.

Healthcare waste was also often found on the conveyor belts and identified by everyone as dangerous: Today I spoke to coordination: too much hospital waste is coming, with needles and syringes.

\section{Chemical hazards}

Participants raised health problems due to inhalation or dermal contact with residues of toxic substances such as cleaning supplies, paints, and solvents, among others. Only one claimed that danger exists in every workplace. I have worked in more dangerous job ${ }^{*}$ than here. However, co-op members were unaware of the toxicity of mercury vapors present inside fluorescent bulbs, as noted in this worker's complaint: The right thing should be for [fluorescent] light bulbs not to come here. When it comes with the material collected, we throw it to the back [area], so no one will step on it and cut his foot.

\section{Physical hazards}

Participants reported that there is always availability of Personal Protective Equipment (PPE) in the shop. However, they admitted that they only wear gloves, boots, and the uniform. It is clear that they ignored the reason why they must wear them: We have everything, but we do not use . ... I don't use mask, they ${ }^{*}$ asphyxiate. Nobody wore hearing protection, despite the acknowledgment that high noise levels exist.

In Co-op B, a forklift was used to elevate workers to unload tubs filled with glass into big containers. In both facilities workers stepped inside those containers (Figure 4) to break up glass manually, using just a hoe or a stick. Moreover, they did not use appropriate safety equipment and often suffered cuts: We don't wear protection because it gets in the way. We only wear gloves, safety glasses, and boots. One of the members even doubted the efficacy of protective equipment: The glove is a partial protection. It is not total. Glass and iron can penetrate the gloves.

Workers did not find that cuts caused by glass, iron, wood, or even punctures from needles to be occupational accidents. Instead, workers believed that most injuries were part of their job and they usually self-medicated: Accidents happen, but small ones, right? I've already fallen once and hurt myself. They mentioned severe cuts that required stitches and two cases of mutilation to the hands. Nobody received worker's compensation for injuries nor were there any preventive 
measure taken to avoid reoccurrence or minimize their severity.

\section{Ergonomic hazards}

Ergonomic hazards are common in recycling work. Only one participant did not complain about ergonomic issues. Back, joint or muscle pain were reported by the others: ...stand up for too long and do the same thing repeatedly! We have two intervals per day, but only for 5 minutes. This cause ${ }^{*}$ pains. When I go home, I'm exhausted. My leg hurts, looks like it will burst, it becomes all stiff and purple. It is because of the movement.

Work absences were frequent and caused work overload for co-op workers: If someone is missing, you have to be a Jack of all trades.

\section{Miscellaneous problems}

Problems of everyday life, such as lack of leisure and excessive commuting time, were also reported. Little resources to spend with public transportation force some members to walk or bike long distances to get to work. One couple, trying to save money, lived in one of the cooperative sites, facing precarious and unhealthy conditions and deprived from daily contact with their families. They were actually trying to avoid the discomfort and costs related to long commutes, rents, and others expenses: I live here, for now. Soon I'm going to look for a house for me. There is nothing like home.

\section{Suggestions for workplace improvements}

Workers suggested better job training and dissemination of information in surrounding communities More campaigns about recycling... so people might sort out better and improve the quality of our work.

An important item in the co-op members' agenda to improve working conditions is more financial resources. In addition, is to amend the quality of recyclables segregated by the population, better worker incomes, and personal satisfaction: There are people with responsibility, by law, to take care of what is waste. Because the support of the city here today is less than 5\%. They could do... give to us much more for the work we do. We go, talk to them and they promise the world, but we just get promises.

One worker recommended improvements of interpersonal relationships, since this was a critical factor and cause of high turnover.

\section{Discussion}

Despite their very low incomes, both teams of workers valued their occupation, were satisfied doing their jobs, and had developed mechanisms to mitigate difficulties. According to Santos and Silva ${ }^{26}$, waste recycling means survival for these workers because they face serious obstacles to enter the labor market due to lack of education and/or opportunities. The same authors argue that recycling workers develop collective and individual response strategies, utilize denial or sublimation to withstand adversity, and may even fail to notice the presence of hazards. There is also a strong tendency to value their work, usually regarded as dirty. Chen $^{27}$ notes this and writes ...where others see trash, recycling workers see paper, cardboard, glass and metal.

Participants showed relatively good knowledge of the benefits of their work regarding waste minimization and environmental conservation. They considered themselves environmental stewards or cleaners of the planet. However, there is a paradox between what they claimed to be and what they practiced at home; while they apparently had a clear understanding of recycling and constantly manipulated recyclable materials, most reported not separating these materials at home.

Even though they were aware of the recyclable collection provided by the municipal service and the existence of ragpickers where they lived, they still did not seem motivated to practice their knowledge as workers at home. Lermen and Fish$\mathrm{er}^{28}$ suggest that the lack of community awareness about issues such as environmental education and preservation follows a general trend of people waiting for government assistance and placing themselves as the last responsible party in environmental matters.

Wage levels are critical for workers in SF. As Castilhos Junior et al. ${ }^{29}$ note, the revenue generated by recycling businesses are often unstable, subject to variations in the volumes of material collected, difficulties related to management capacity, and price fluctuations in the recycling market. This lack of financial stability has divided workers who have, in turn, accused each other of unnecessary absenteeism. Workers see this as causing a reduction in the overall production, which lowers their incomes since it is based on the division of surpluses. Nevertheless, absence from work and high staff turnover, factors that limit productivity, were not perceived to be associated with a weakness in the hiring system. 
The Brazilian program called Pro-Catador ${ }^{30}$ was enacted by law in 2010 with the intent of giving more support and encouragement to recycling organizations, improving working conditions, increasing social and economic inclusion, and expanding selective collection and recycling. However, so far, it has not led to significant improvements in the sector.

This study reveals that inadequacies of infrastructure, logistics, and organization of work harm worker health and safety. Improper material storage conditions, degradation of organic matter mixed with recyclables, and attraction and proliferation of vectors are biological hazards. Site observations discovered that toxic products, electronic equipment, and a variety of dangerous medical waste, such as materials contaminated with blood, chemicals, used syringes and unprotected needles were present in SF.

Most of the injuries suffered were not recognized as workplace accidents by the workers and consequently not included in the official reports. Co-op members do not stop working to seek medical care unless the injury is serious. Studies in Brazil $^{9}$ and other countries ${ }^{12,31}$ also reveal that SF operate in an unhealthy and unsafe manner. According to Ballesteros et al. ${ }^{31}$, who compared the health status of recycling workers organized in associations with independent ones, there is similar morbidity for both groups without any gain in work quality for the former.

Back pain is a symptom often related to ergonomic hazards and excessive job workload. It is common in manual labor or operation of lowtech equipment with obsolete tools, inappropriately designed workplaces (often originally built for other purposes), and limited budgets to address occupational safety, health issues, and prevention of diseases ${ }^{7}$. Cointreau ${ }^{13}$ notes that while developed countries have adopted automated sorting and processing systems with the goal of preventing workplace risks and accidents, developing countries still use manual processes that are linked to a higher probability of injuries.

Previous research $s^{12,13}$ revealed that activities such as weight lifting, manual maneuvers, prolonged bending, and repetitive tasks increase the prevalence of musculoskeletal injuries in the upper and lower parts of the back of waste collectors and recycling workers. Regardless of the work performed, our study participants complained about muscle pain, and joint and physical fatigue. These are frequently associated with repetitive work, prolonged standing, excessive weight lifting, and few breaks. Moreover, workers ignored the existence of preventive measures or alternatives to minimize physical effort and injuries.

Workers did not mention several other potentially hazardous exposures, such as excessive noise; air pollution due to dust and internal movement of vehicles; lack of machine guarding on conveyor belts and presses; presence of mold; toxicity of heavy metals (e.g. mercury, copper, or cadmium), among others. Health damages such as hearing loss, respiratory diseases, and stress were not discussed nor associated with the work environment, although field observations have identified them. One severe episode of mutilation of fingers was attributed to human error. The hazardous manual fragmentation of glass continued to be a routine practice without considering alternative ways of doing it.

Dall'Agnol and Fernandes ${ }^{32}$ argue that as the primary objective of these workers is to ensure survival for themselves and their families, consequently, there is a tendency to ignore hazardous situations, considering them as part of the job and not a result of poor working conditions. Van Eerd ${ }^{2}$ suggests that preventive measures that eliminate hazards at the source are preferable to palliative or curative approaches, though personal protection equipment (PPE) should not be ignored in occupational safety and health programs.

This study showed that occupational safety and health care has been neglected; workers were not aware of workplace risks and not monitored for use of PPE. A similar situation was reported by Almeida et al. ${ }^{33}$, who studied recycling workers in Minas Gerais, Brazil. Although workers had access to gloves, boots, masks and gowns, they did not wear them, nor did the coordinating team requires them to wear PPE.

We also confirmed the findings of Dall'Agnol and Fernandes ${ }^{32}$ and Almeida et al. ${ }^{33}$, who described workers' practice of selecting for themselves clothing, toys, appliances, personal use items, and food from the waste received as recyclables. This practice calls for better training of recycling workers and the need to motivate the population to segregate waste more carefully to improve the quality of recyclables sent to SF.

\section{Conclusion}

In Brazil, selective collection and sorting of recyclables in partnership with recycling workers is part of a public policy that aims at covering three 
sustainability areas: environmental (reduction of pollution to the air, water and soil), economic (solid waste recovery) and social (promotion of employment and income for a historically excluded population). However, the municipal programs of selective collection implemented in most Brazilian municipalities still need improvements to achieve their goals and objectives, especially in the case of workers.

Organizing Brazilian recycling workers in cooperatives as a replacement to informal garbage sorting in streets and landfills provided very little improvement to the system of selective collection. In addition, it achieved small progress regarding the health and safety and the quality of life for co-op workers.

Despite having a low-level of education and no job training, recycling workers could identify risky situations in the SF. They seemed resigned to the status quo, resistant to incorporate new practices or change in behaviors, and did not usually communicate needs to their supervisors. Sometimes, they even created operational practices and alternatives that endangered their own health.

This study adds to the current literature through an in-depth and participatory view of working conditions in sorting facilities. Our findings can't be generalized to all Brazilian recycling workers' organizations due to local differences, such as the quality and coverage of municipal programs, healthcare access, legal support to workers, and especially the level of population adherence to recycling programs.

An interesting behavioral duality was discovered among recycling workers: while at work they promoted proper waste segregation, but at home they acted as average citizens unaware of recycling programs. If their professional activities aim at sustainability, why it is not incorporated into their daily lives? Future studies should further investigate this contradiction.

We have the following suggestions to improve SFs: a) an implementation of participatory management practices, including discussion of demands, complaints and suggestions with the recycling workers; b) financial, legal and technical support to the cooperatives; c) restructuring of work organization; d) provision of job training programs; e) implementation of protective measures to eliminate or reduce work environment and health hazards; f) access to healthcare for disease prevention and treatment; and g) dissemination of information to the public in order to improve waste segregation at the source.

\section{Collaborations}

AMM Moreira and WMR Günther participated designing the study; collecting and analyzing data; writing and revising the text. CEG Siqueira participated on the methodology; analyzing data; writing and revising the text.

\section{Acknowledgments}

The authors gratefully acknowledge the participation of the recycling workers in this study.

\section{References}

1. Besen GR, Ribeiro H, Günther WM; Jacobi PR. Coleta seletiva na região metropolitana de São Paulo: impactos da Política Nacional de Resíduos Sólidos. Ambient soc 2014; 17(3):259-278.

2. Van Eerd M. The occupational health aspects of waste collection and recycling: a survey of the literature. Amsterdam: Urban Waste Expertize Programme (UWEP); 1996.

3. Ezeah C, Fazakerley JA, Roberts CL. Emerging trends in informal sector recycling in developing and transition countries. Waste Management 2013; 33(11):2509-2519.

4. Medina M. Scavenger cooperatives in Asia and Latin America. Resources, Conservation and Recycling 2000; 31(1):51-69.

5. Brasil. Portaria no 397, de 09 de outubro de 2002. Aprova a Classificação Brasileira de Ocupações - CBO. Diário Oficial da União 2002; 10 out. 
6. Johannes GP, Joan A, Neil R, Salome PV. Integration of the informal sector into municipal solid waste management in the Philippines - What does it need? Waste Management 2012; 32(11):2018-2028.

7. Van Zeeland AJ. The interaction between popular economy, social movements and public policies - A case study of the waste pickers' movement. Geneva: United Nations Research Institute for Social Development (UNRISD); 2014.

8. Medina M. Serving the unserved: informal refuse collection in Mexico. Waste Manag Res 2005; 23(5):390397.

9. Campos HK. Recycling in Brazil: Challenges and prospects. Resources, Conservation and Recycling 2014; 85:130-138.

10. Medeiros LFR, Macêdo, KB. Catador de material reciclável: uma profissão para além da sobrevivência? Psicologia \& Sociedade 2006; 18(2):62-71

11. Brasil. Ministério da Saúde. Portaria no 1.823 , de 23 de agosto de 2012. Institui a Política Nacional de Saúde do Trabalhador e da Trabalhadora. Diário Oficial da União 2012; 24 ago.

12. Lavoie J, Guertin S. Evaluation of health and safety risks in municipal solid waste recycling plants. Journal of the Air \& Waste Management Association 2001; 51(3):352-360.

13. Cointreau S. Occupational and environmental health issues of solid waste management. New York: The International Bank for Reconstruction and Development, The World Bank; 2006.

14. Brasil. Ministério da Saúde (MS). Organização Pan-Americana da Saúde no Brasil (OPAS). Doenças relacionadas ao trabalho: manual de procedimentos para os serviços de saúde. Brasília: MS; 2001.

15. Geer LA, Curbow BA, Anna DH, Lees PSJ, Buckley TJ. Development of a questionnaire to assess worker knowledge, attitudes and perceptions underlying dermal exposure. Scand J Work Environ Health 2006; 32(3):209-218.

16. Renn O. Concepts of risk: a classification. In: Krimsky S, editor. Social theories of risk. Westport: Praeger; 1992. p. 53-79.

17. Dejours C. A loucura do trabalho. São Paulo: Ed. Cortez; 1992.

18. Cavalcante $S$, Franco MFA. Percepção de risco à saúde entre os catadores do Lixão do Jangurussu. Revista Mal-estar e Subjetividade 2007; 7(1):211-231.

19. Cardozo M. Percepção de riscos ambientais de trabalhadores catadores de materiais recicláveis em um aterro controlado do município de Duque de Caxias, RJ [dissertação] Rio de Janeiro: Escola Nacional de Saúde Pública Sergio Arouca; 2009.

20. Oliveira DAM. Percepção de riscos ocupacionais em catadores de materiais recicláveis: estudo em uma Cooperativa em Salvador-Bahia [dissertação]. Salvador: Universidade Federal da Bahia; 2011.

21. Gibbs A. Focus Groups. Social Research Update 1997. Guildford: University of Surrey Guildford; 1997.
22. Kitzinger J. Focus Group Research: using group dynamics to explore perceptions, experiences and understandings. Holloway I, editor. Qualitative Research in Health Care. Maidenhead: Open University Press; 2005. p. 56-70.

23. Wang C, Burris MA. Photovoice: Concept, Methodology, and Use for Participatory Needs Assessement. Health Educ Behav 1997; 24(3):369-387

24. Flum MR, Siqueira CD, DeCaro A, Redway S. Photovoice in the workplace: a participatory method to give voice to workers to identify health and safety hazards and promote workplace change - a study of university custodians. Am J Ind Med 2010; 53(11):1150-1158.

25. Bardin L. Análise de conteúdo. Lisboa: Edições 70; 2009.

26. Santos GO, Silva FF. Os significados do lixo para garis e catadores de Fortaleza (CE, Brasil). Cien Saude Colet 2011; 16(8):3413-3419.

27. Chen M. Waste global challenge, Latin American lessons. ReVista - Harvard Review of Latin America 2015; $14(2): 2-6$.

28. Lermen HS, Fisher PD. Percepção ambiental como fator de saúde pública em área de vulnerabilidade social no Brasil. Rev APS 2010; 13(1):62-71.

29. Castilhos Junior AB, Ramos NF, Alves CM, Forcellini FA, Graciolli OD. Catadores de materiais recicláveis: análise das condições de trabalho e infraestrutura operacional no sul, sudeste e nordeste do Brasil. Cien Saude Colet 2013; 18(11):3115-3124.

30. Brasil. Decreto no 7.405, de 23 de dezembro de 2010. Institui o Programa Pró-Catador, denomina Comitê Interministerial para Inclusão Social e Econômica dos Catadores de Materiais Reutilizáveis e Recicláveis o Comitê Interministerial da Inclusão Social de Catadores de Lixo criado pelo Decreto de 11 de setembro de 2003, dispõe sobre sua organização e funcionamento, e dá outras providências. Diário Oficial da União 2012; 23 dez.

31. Ballesteros VL, Arango YLL, Urrego YMC. Condiciones de salud y de trabajo informal en recuperadores ambientales del área rural de Medellín, Colombia, 2008. Rev Saude Publica 2012; 46(5):866-874.

32. Dall'Agnol CM, Fernandes FS. Saúde e autocuidado entre catadores de lixo: vivências no trabalho em uma cooperativa de lixo reciclável. Rev Latino-am Enfermagem 2007; 15(n. esp.):729-735.

33. Almeida JR, Elias ET, Magalhães, MA, Vieira AJ. Efeito da idade sobre a qualidade de vida e saúde dos catadores de materiais recicláveis de uma associação em Governador Valadares, Minas Gerais, Brasil. Cien Saude Colet 2009; 14(6):2169-2179.

Artigo apresentado em 17/07/2016

Aprovado em 08/07/2017

Versão final apresentada em 10/07/2017 